\title{
Cardiovascular responses produced by central injection of hydrogen peroxide in conscious rats
}

\author{
Leonardo Máximo Cardoso ${ }^{\mathrm{a}}$, Débora Simões de Almeida Colombari ${ }^{\mathrm{b}}$, José Vanderlei Menani ${ }^{\mathrm{b}}$, \\ Deoclécio Alves Chianca Jr. ${ }^{\mathrm{c}}$, Eduardo Colombari ${ }^{\mathrm{a}, \mathrm{b}, *}$ \\ ${ }^{a}$ Department of Physiology, Federal University of São Paulo (UNIFESP), Rua Botucatu, 862, 04023-060 São Paulo, SP, Brazil \\ ${ }^{\mathrm{b}}$ Department of Physiology and Pathology, State University of São Paulo (UNESP), Araraquara, SP, Brazil \\ ${ }^{\mathrm{c}}$ Department of Biological Sciences, Federal University of Ouro Preto (UFOP), Ouro Preto, MG, Brazil
}

Received 22 December 2005; received in revised form 22 July 2006; accepted 24 July 2006

Available online 14 August 2006

\begin{abstract}
Reactive oxygen species (ROS) have been shown to modulate neuronal synaptic transmission and may play a role on the autonomic control of the cardiovascular system. In this study we investigated the effects produced by hydrogen peroxide $\left(\mathrm{H}_{2} \mathrm{O}_{2}\right)$ injected alone or combined with the anti-oxidant agent $\mathrm{N}$-acetil-L-cysteine (NAC) or catalase into the fourth brain ventricle (4th $\mathrm{V}$ ) on mean arterial pressure and heart rate of conscious rats. Moreover the involvement of the autonomic nervous system on the cardiovascular responses to $\mathrm{H}_{2} \mathrm{O}_{2}$ into the 4 th $\mathrm{V}$ was also investigated. Male Holtzman rats (280-320 g) with a stainless steel cannula implanted into the 4th $\mathrm{V}$ and polyethylene cannulas inserted into the femoral artery and vein were used. Injections of $\mathrm{H}_{2} \mathrm{O}_{2}(0.5,1.0$ and $1.5 \mu \mathrm{mol} / 0.2 \mu \mathrm{L}, n=6)$ into the 4 th $\mathrm{V}$ produced transient (for 10 min) dose-dependent pressor responses. The 1.0 and $1.5 \mu \mathrm{mol}$ doses of $\mathrm{H}_{2} \mathrm{O}_{2}$ also produced a long lasting bradycardia (at least $24 \mathrm{~h}$ with the high dose of $\mathrm{H}_{2} \mathrm{O}_{2}$ ). Prior injection of $N$-acetyl-L-cysteine $(250 \mathrm{nmol} / 1 \mu \mathrm{L} / \mathrm{rat})$ into the 4 th $\mathrm{V}$ blockade the pressor response and attenuated the bradycardic response to $\mathrm{H}_{2} \mathrm{O}_{2}$ $(1 \mu \mathrm{mol} / 0.5 \mu \mathrm{L} / \mathrm{rat}, n=7)$ into the $4 \mathrm{th} \mathrm{V}$. Intravenous (i.v.) atropine methyl bromide $(1.0 \mathrm{mg} / \mathrm{kg}, n=11)$ abolished the bradycardia but did not affect the pressor response to $\mathrm{H}_{2} \mathrm{O}_{2}$. Prazosin hydrochloride $(1.0 \mathrm{mg} / \mathrm{kg}, n=6)$ i.v. abolished the pressor response but did not affect the bradycardia. The increase in the catalase activity ( $500 \mathrm{UEA} / 1 \mu \mathrm{L} /$ rat injected into the 4 th $\mathrm{V}$ ) also abolished both, pressor and bradycardic responses to $\mathrm{H}_{2} \mathrm{O}_{2}$. The results suggest that increased ROS availability into 4th $\mathrm{V}$ simultaneously activate sympathetic and parasympathetic outflow inducing pressor and bradycardic responses.
\end{abstract}

(C) 2006 Elsevier Inc. All rights reserved.

Keywords: Hydrogen peroxide; Blood pressure; Heart rate; Prazosin; Methyl atropine; N-Acetyl-L-cysteine; Anti-oxidant

\section{Introduction}

Considerable evidence suggests that reactive oxygen species (ROS) such as superoxide anion $\left(\mathrm{O}_{2}{ }^{\bullet-}\right)$, hydrogen peroxide $\left(\mathrm{H}_{2} \mathrm{O}_{2}\right)$ and hydroxyl radical $\left(\mathrm{HO}^{\bullet}\right)$ may act as cellular signaling molecules to regulate biological function (reviewed in $[1,34])$. ROS are the result of incomplete reduction of oxygen to $\mathrm{O}_{2}{ }^{\bullet-}$ which is spontaneously or enzymatically dismutated to $\mathrm{H}_{2} \mathrm{O}_{2}$ [19]. Different types of cells can produce $\mathrm{O}_{2}{ }^{\bullet-}$ and $\mathrm{H}_{2} \mathrm{O}_{2}$

Abbreviations: CVLM, caudal ventrolateral medulla; HR, heart rate; MAP, mean arterial pressure; NTS, nucleus of the tract solitary; NAC, N-acetil-Lcysteine; RVLM, rostral ventrolateral medulla; SOD, superoxide dismutase; 4 th $\mathrm{V}$, fourth brain ventricle; UEA, units of enzymatic activity

* Corresponding author. Tel.: +55 1150849554.

E-mail address: colombari@fcr.epm.br (E. Colombari). in response to a variety of extracellular stimuli, like cytokines, peptide growth factors, agonists of heterotrimeric G proteincoupled receptors (angiotensin II, thrombin, lysophosphatidic acid, sphingosine 1-phosphate, histamine and bradykinin) and sheer stress (reviewed in [34]). It was previously demonstrated that $\mathrm{H}_{2} \mathrm{O}_{2}$ in the central nervous system (CNS) modulates synaptic transmission [16,31]. The reversibility of $\mathrm{H}_{2} \mathrm{O}_{2}$ effects on synaptic transmission and the demonstration that similar effects are seen with endogenously generated, as well as exogenously added $\mathrm{H}_{2} \mathrm{O}_{2}[3,9]$ have implicated the $\mathrm{H}_{2} \mathrm{O}_{2}$ as an endogenous neuromodulator [4].

A select group of brainstem nuclei play critical roles in the maintenance of cardiovascular homeostasis and in the pathophysiology of the hypertension $[13,33]$. Recent finds suggest that endogenously generated ROS in medullary neurons could play a role in the autonomic control of the blood pressure as 
indicated by the co-localization of angiotensinergic receptors $\left(\mathrm{AT}_{1}\right)$ and the gp91 ${ }^{\text {phox }}$ subunit of the $\mathrm{O}_{2}{ }^{\bullet-}$ generating enzyme NADPH oxidase in somatodendrids and axons of neurons in the nucleus of the solitary tract (NTS) [40]. Furthermore, the activity of neurons in the rostroventrolateral medulla (RVLM), an important source of sympathetic output to cardiovascular system, is suggested to be modulated by ROS [21,22,43]. Results with injections of superoxide dismutase (SOD) [43], SOD mimetics like tempol [22] or genetic manipulations that induce overexpression of SOD in the RVLM [22] have suggested that $\mathrm{O}_{2}{ }^{\bullet-}$ is a pivotal ROS in the generation/maintenance of sympathetic output. However, the role of the $\mathrm{H}_{2} \mathrm{O}_{2}$ or the effects of a possible interaction between $\mathrm{H}_{2} \mathrm{O}_{2}$ and $\mathrm{O}_{2}{ }^{\bullet-}$ into the medulla remain to be investigated.

The increase in sympathetic activity is believed to play an important role in the development and maintenance of the hypertension [11]. Experimental [5,20,22,24,32,39,41] and clinical tests $[8,17,23]$ have suggested that disruptions of the reduction/oxidation (redox) state may be associated with hypertension. For instance, clinical studies reported that hypertensive patients exhibited significantly higher production of blood $\mathrm{H}_{2} \mathrm{O}_{2}$ than normotensive subjects and among normotensive, those subjects with a family history of hypertension had increased production of blood $\mathrm{H}_{2} \mathrm{O}_{2}$ [23]. However, the relationship between ROS and hypertension is still not well established as well as the mechanisms by which alterations in the redox state could be linked to hypertension or other cardiovascular diseases.

The understanding on how central $\mathrm{H}_{2} \mathrm{O}_{2}$ and redox state can modulate cardiovascular function is an important step for a best interpretation on how anti-oxidant species might be applied in therapeutic profiles. Since endogenous systems generating $\mathrm{O}_{2}{ }^{\bullet-}$, and consequently $\mathrm{H}_{2} \mathrm{O}_{2}$, were identified into the medulla [40], we hypothesized that $\mathrm{H}_{2} \mathrm{O}_{2}$ acting in medullary networks could affect sympathetic and/or parasympathetic output controlling cardiovascular system. Therefore, in this study, we investigated the possible mechanisms activated by an oxidative burst produced by injections of $\mathrm{H}_{2} \mathrm{O}_{2}$ into the fourth ventricle to induce cardiovascular responses in unanaesthetized rats.

\section{Materials and methods}

\subsection{Animals}

Studies were performed in male Holtzman rats (51 animals), weighing 280-320 g, from the main breeding stock of animal facility from Dentistry School, State University of São Paulo (UNESP). Animals were housed in individual cages in a room with controlled temperature $\left(22 \pm 3^{\circ} \mathrm{C}\right)$ and humidity (40-60\%) and received rat chow (Guabi Rat Chow, Paulinia, SP, Brazil) and water ad libitum. Lights were on from 7 a.m. to 7 p.m. All experiments were done in accordance with the Brazilian Society for Neuroscience and Behavior Guidelines for Animal Experimentation and had the approval of the institutional animal care and use committee of the Federal University of São Paulo/Escola Paulista de Medicina (process no. 0670/04). All efforts were made to minimize animal suffering and limit the number of animals used for these experiments.

\subsection{Drugs}

Hydrogen peroxide, catalase (from bovine liver, $2860 \mathrm{UEA} / \mathrm{mg}$ of powder) atropine methyl bromide, prazosin $\mathrm{HCl}$ and $\mathrm{N}$-acetil-L-cysteine (NAC) were purchased from Sigma-Aldrich Co. Hydrogen peroxide, atropine methyl bro- mide and prazosin $\mathrm{HCl}$ were diluted in phosphate buffer saline (PBS, $\mathrm{pH}$ 7.2). $\mathrm{N}$-Acetil-L-cysteine was neutralized with bicarbonate $(1 \mathrm{~mol} / \mathrm{L})$ and the final volume completed with PBS right before the experiments. Catalase was diluted in PBS right before the injections.

\subsection{Cerebral surgery}

Rats were anesthetized with i.p. injections of ketamine $(80 \mathrm{mg} / \mathrm{kg}$, body weight) combined with xilazine $(7 \mathrm{mg} / \mathrm{kg}$, body weight) (Cristalia Produtos Químicos e Farmacêuticos, Itapira, SP) and placed in a Stoelting stereotaxic instrument. An incision was made through the skin on the skull to expose bregma and lambda that were positioned at the same horizontal plane. A stainless steel cannula $(12.0 \mathrm{~mm} \times 0.6 \mathrm{~mm}$ o.d.) was implanted in the midline, $13.0 \mathrm{~mm}$ caudal to bregma and $6.0 \mathrm{~mm}$ below the skull surface, directed to the fourth 4 th V. Two jeweler screws were implanted in the skull, and the cannula was fixed to the screws with acrylic cement. At the end of the surgery, rats received an intramuscular injection with 30,000 IU of penicillin (Fort Dodge Saúde Animal Ltda, Campinas, SP), and they were placed in individual cages with chow and water ad libitum.

\subsection{Arterial pressure and heart rate recording}

Three days after brain surgery, under ketamine plus xilazine anesthesia, a polyethylene catheter (PE-10 connected to PE-50, Clay Adams, Parsippany, NJ, USA), filled with heparinized saline $(125 \mathrm{IU} / \mathrm{mL})$, was inserted into the aorta through the right femoral artery for measurement of pulsatile arterial pressure (PAP). A second catheter was inserted into the inferior vena cava through the right femoral vein for administration of drugs. The free ends of the catheters were tunneled subcutaneously and exteriorized at the back of the neck. During the experiments, cannulas were connected to a swivel and this to a Stathan Gould pressure transducer connected to an analog-to-digital data acquisition system (PowerLab 16Sp; ADInstruments, Australia). Data were collected at a $400 \mathrm{~Hz}$ sampling rate. Heart rate (HR) and mean arterial pressure (MAP) were derived on-line from the pulsatile arterial pressure signal with Chart 4.12 for windows software (ADInstruments, Australia). All experiments were performed in unanesthetized freely moving rats, approximately $24 \mathrm{~h}$ after the cannulation surgery.

\subsection{Injections into the fourth ventricle}

Injections into the 4 th $\mathrm{V}$ were made with $10 \mu 1$ Hamilton syringes connected by polyethylene tubing (PE-10) to an injector needle. The injector, when completely inserted, protruded $2 \mathrm{~mm}$ beyond the tip of the guide cannula. Injections in the 4 th $\mathrm{V}$ were $0.2-1.0 \mu \mathrm{l}$ for about $5-10 \mathrm{~s}$.

\subsection{Dose-response curve for $\mathrm{H}_{2} \mathrm{O}_{2}$}

After $20 \mathrm{~min}$ of arterial pressure and HR recording, six animals received injections of PBS and $\mathrm{H}_{2} \mathrm{O}_{2}$ at the doses of $0.1,0.5$ and $1.0 \mu \mathrm{mol} / 0.2 \mu \mathrm{L} / \mathrm{rat}$. PBS or the different doses of $\mathrm{H}_{2} \mathrm{O}_{2}$ were randomly injected into 4th $\mathrm{V}$ with an interval of $15 \mathrm{~min}$ between injections (a period enough for the returning of arterial pressure to the baseline pre-injection value after one injection). To compare with the effects of $\mathrm{H}_{2} \mathrm{O}_{2}$ injections, a separated group of five animals received just five injections of PBS (vehicle group). In these two groups of animals, baseline arterial pressure and HR were also measured $24 \mathrm{~h}$ after the injections. An additional group of eight animals received $\mathrm{PBS}$ and $\mathrm{H}_{2} \mathrm{O}_{2}$ at the dose of $1.5 \mu \mathrm{mol} / \mathrm{rat}$ into the 4 th $\mathrm{V}$. In this group, baseline arterial pressure and HR were also measured 24 and $48 \mathrm{~h}$ after the injections. For all three groups we evaluated the maximum changes in MAP and HR induced by the injections of $\mathrm{H}_{2} \mathrm{O}_{2}$.

\subsection{Treatment with atropine methyl bromide and prazosin hydrochloride}

Injections of $\mathrm{H}_{2} \mathrm{O}_{2}(1 \mu \mathrm{mol} / \mathrm{rat})$ into the 4 th $\mathrm{V}$ were carried out $1 \mathrm{~h}$ before and $15 \mathrm{~min}$ after an i.v. injection of vehicle (PBS), atropine methyl bromide 
$(1.0 \mathrm{mg} / \mathrm{kg}$ of body weight) or prazosin hydrochloride $(1.0 \mathrm{mg} / \mathrm{kg}$ of body weight). To quantify the effect of the muscarinic and $\alpha_{1}$ adrenergic blockades, we compared the maximum changes in MAP and HR induced by injections of $\mathrm{H}_{2} \mathrm{O}_{2}$ into the 4 th $\mathrm{V}$ before and after i.v. injections of the atropine and prazosin, as well as the changes induced by $\mathrm{H}_{2} \mathrm{O}_{2}$ after injection of vehicle.

\subsection{Treatment with catalase}

Catalase enzyme (500 UEA), an enzymatic scavenger of $\mathrm{H}_{2} \mathrm{O}_{2}$, or vehicle were injected into the 4th $\mathrm{V}$ 2-4 min before an injection of $\mathrm{H}_{2} \mathrm{O}_{2}$ $(1.0 \mu \mathrm{mol} / 0.5 \mu \mathrm{L} / \mathrm{rat})$. Forty eight hours later the animals were tested again in a counterbalanced design i.e., those that had received catalase in the first test received vehicle in the second test and vice-versa.

\subsection{Treatment with $N$-acetil-L-cysteine $(N A C)$}

In a group of seven animals, NAC $(250 \mathrm{nmol} / 1 \mu \mathrm{L} / \mathrm{rat})$, a thiol antioxidant, was injected into the 4 th $\mathrm{V} \mathrm{2-5} \mathrm{min} \mathrm{before} \mathrm{an} \mathrm{injection} \mathrm{of} \mathrm{H}_{2} \mathrm{O}_{2}$ $(1.0 \mu \mathrm{mol} / 0.5 \mu \mathrm{L} / \mathrm{rat})$. In an another group of seven animals, vehicle (PBS) was injected into the 4th $\mathrm{V} 2-5 \mathrm{~min}$ before the injection of $\mathrm{H}_{2} \mathrm{O}_{2}$.

\subsection{Histology}

At the end of the experiments, $0.2 \mu \mathrm{L}$ of $2 \%$ Evans blue solution was injected into the 4th V. Immediately after the injection, the animals were deeply anesthetized with sodium thiopental $(70 \mathrm{mg} / \mathrm{kg}$ of body weight, i.v.), and perfused through the heart with $0.9 \% \mathrm{NaCl}$ followed by $10 \%$ buffered formalin. The brains were removed, frozen, cut coronally in $70 \mu \mathrm{m}$ sections, stained with Giemsa stain and analyzed by light microscopy to confirm the presence of dye in the 4 th $\mathrm{V}$. Fig. 1 is a photomicrograph of a hindbrain slice showing the site of injection into the 4 th $\mathrm{V}$ in one rat of the rats tested.

\subsection{Statistical analysis}

The results were reported as means \pm standard error of means (S.E.M.) Analysis of variance (ANOVA) for repeated measures followed by post hoc pairwise multiple comparisons Student-Newman-Keuls test or paired and nonpaired $t$-tests were used. For dose-response evaluation, the Bonferroni correction was used to adjust Type I error values for the post hoc tests. Differences were considered significant when the probability of a Type I error was less than $5 \%$ $(p<0.05)$

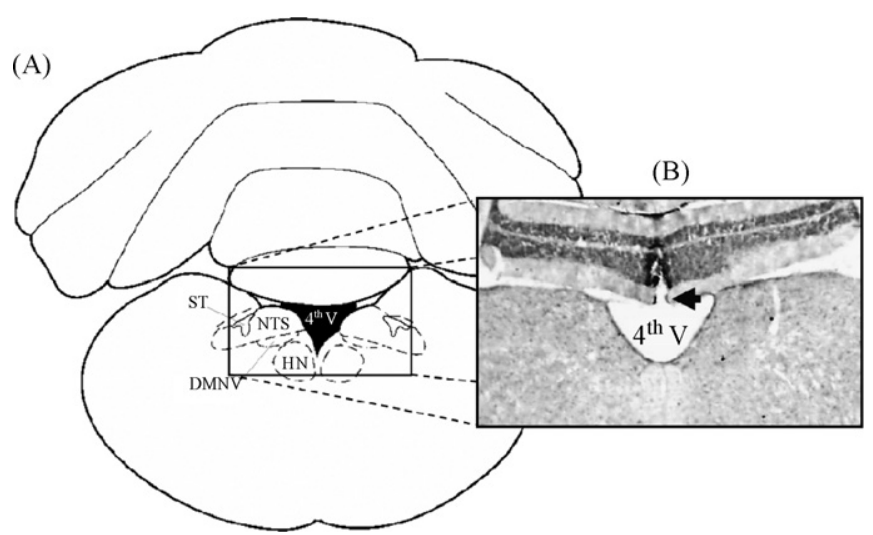

Fig. 1. (A) Schematic draw of a rat brain coronal slice showing the medulla and cerebellum (13.3 mm caudal to bregma). ST, solitary tract; NTS, nucleus tractus solitari; DMNV, dorsal motor nucleus of vagus; HN, hypoglossal nucleus; 4th $\mathrm{V}$, fourth ventricle. The rectangle in (A) corresponds to the area presented in the photomicrograph (B) at the same coronal section level showing the tract of injector needle directed to the 4th V (arrow). Schematic draw adapted from Paxinos and Watson [29].

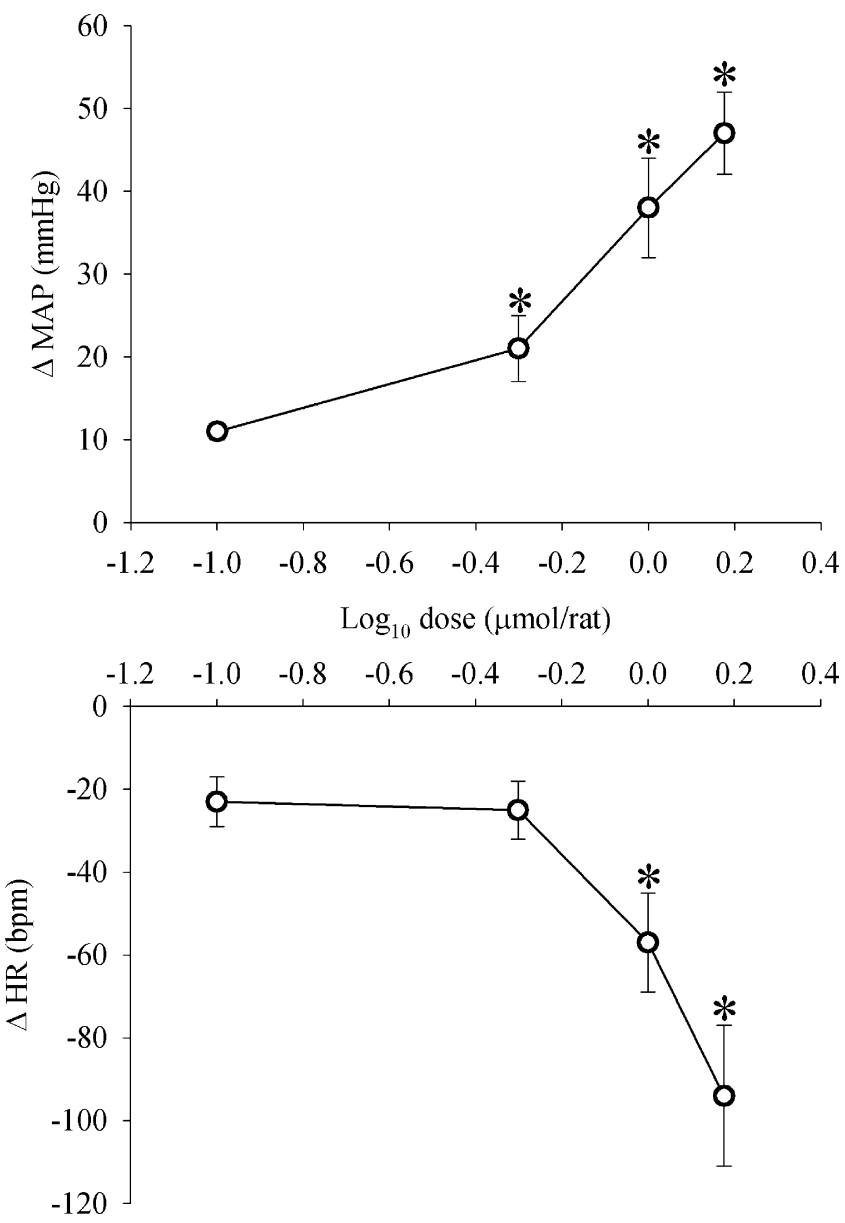

Fig. 2. Changes in MAP $(\triangle \mathrm{MAP})$ and $\mathrm{HR}(\Delta \mathrm{HR})$ produced by $\mathrm{H}_{2} \mathrm{O}_{2}(0.1$, $0.5,1.0$ and $1.5 \mu \mathrm{mol}$ ) injected into the 4 th $\mathrm{V}$. Abscissa represents the log dose of $\mathrm{H}_{2} \mathrm{O}_{2}$. ${ }^{*}$, Different from vehicle (ANOVA followed by Bonferroni $t$-test, $p<0.05) ; n=6$.

\section{Results}

\subsection{Effects of $\mathrm{H}_{2} \mathrm{O}_{2}$ injected into the 4th $\mathrm{V}$ on MAP and $\mathrm{HR}$}

Injections of $\mathrm{H}_{2} \mathrm{O}_{2}(0.5,1.0$ and $1.5 \mu \mathrm{mol} / \mathrm{rat})$ into the 4th $\mathrm{V}$ produced a dose-dependent increase in MAP (Fig. 2). Mean arterial pressure peaked from 20 to $100 \mathrm{~s}$ after the injections of $\mathrm{H}_{2} \mathrm{O}_{2}$ into the 4th $\mathrm{V}$ and returned to baseline pre-injection level from 5 to $10 \mathrm{~min}$ after the injections.

Injections of $\mathrm{H}_{2} \mathrm{O}_{2}(1.0$ and $1.5 \mu \mathrm{mol} / \mathrm{rat})$ into the 4 th $\mathrm{V}$ also produced bradycardia that peaked between 2 and 5 min after the injections (Fig. 2). The bradycardia was maintained for at least $24 \mathrm{~h}$ (but not for $48 \mathrm{~h}$ ) with the $1.5 \mu \mathrm{mol}$ dose of $\mathrm{H}_{2} \mathrm{O}_{2}$ into the 4th $\mathrm{V}$, while with the $1 \mu \mathrm{mol}$ dose, HR had already returned to baseline pre-injection level $24 \mathrm{~h}$ after the injection (Table 1).

\subsection{Effect of the pre-treatment with NAC into 4th $\mathrm{V}$ on central $\mathrm{H}_{2} \mathrm{O}_{2}$-induced pressor and bradycardic responses}

The treatment with NAC $(250 \mathrm{nmol} / 1 \mu \mathrm{L} / \mathrm{rat})$ into the 4 th $\mathrm{V}$ did not affect baseline MAP $(109 \pm 2 \mathrm{mmHg}$ before versus $111 \pm 2 \mathrm{mmHg}$ after; $p=0.305$; non-paired $t$-test) or HR 
Table 1

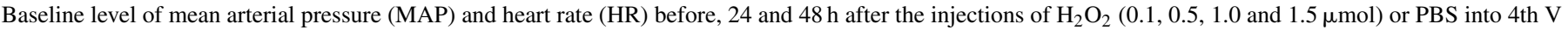

\begin{tabular}{|c|c|c|c|c|c|c|}
\hline \multirow[t]{2}{*}{ Treatment } & \multicolumn{2}{|c|}{ Before injections } & \multicolumn{2}{|c|}{$24 \mathrm{~h}$ after injections } & \multicolumn{2}{|c|}{$48 \mathrm{~h}$ after injections } \\
\hline & MAP (mmHg) & HR (bpm) & MAP (mmHg) & HR (bpm) & MAP (mmHg) & $\mathrm{HR}(\mathrm{bpm})$ \\
\hline Vehicle (PBS) & $115 \pm 4$ & $381 \pm 13$ & $112 \pm 4$ & $372 \pm 13$ & - & - \\
\hline $0.1-1.0 \mu \mathrm{mol}$ & $111 \pm 3$ & $349 \pm 12$ & $117 \pm 4$ & $363 \pm 13$ & - & - \\
\hline $1.5 \mu \mathrm{mol}$ & $113 \pm 3$ & $366 \pm 11$ & $118 \pm 4$ & $292 \pm 8^{*}$ & $128 \pm 9$ & $370 \pm 13$ \\
\hline
\end{tabular}

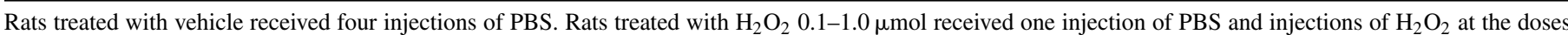

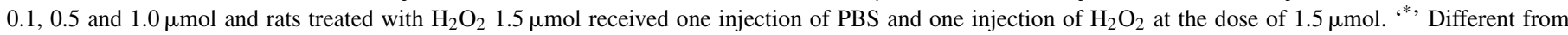

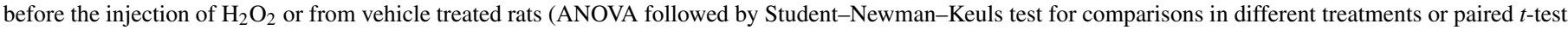
for comparisons before and after the treatment, $p<0.05)$. vehicle, $n=5, \mathrm{H}_{2} \mathrm{O}_{2}, 0.1-1.0 \mu \mathrm{mol}, n=6, \mathrm{H}_{2} \mathrm{O}_{2} 1.5 \mu \mathrm{mol}, n=8(48 \mathrm{~h}$ after injections, $n=4)$.

(354 $\pm 14 \mathrm{bpm}$ before versus $353 \pm 13$ after; $p=0.854$; nonpaired $t$-test).

The treatment with NAC abolished the pressor response (vehicle: $38 \pm 4 \mathrm{mmHg}$ versus NAC: $10 \pm 4 \mathrm{mmHg} ; p<0.001$; $n=7$; non-paired $t$-test), and attenuated the bradycardic response by $61 \%$ (vehicle: $-67 \pm 7 \mathrm{bpm}$ versus NAC: $-26 \pm 8 \mathrm{bpm} ; p=0.002 ; n=7$; non-paired $t$-test) induced by $\mathrm{H}_{2} \mathrm{O}_{2}(1 \mu \mathrm{mol} / 0.5 \mu \mathrm{L} / \mathrm{rat})$ into the 4 th $\mathrm{V}$ (Fig. 3).

\subsection{Effect of the pre-treatment with catalase into the 4th $V$ on central $\mathrm{H}_{2} \mathrm{O}_{2}$-induced pressor and bradycardic responses}

Catalase (500 UEA/1 $\mu \mathrm{L} /$ rat) into the 4 th $\mathrm{V}$ did not affect baseline MAP $(118 \pm 3 \mathrm{mmHg}$ before versus $116 \pm 5 \mathrm{mmHg}$ after, paired $t$-test; $n=6 ; p=0.685)$ but slightly reduced baseline HR $(377 \pm 19 \mathrm{bpm}$ before versus $345 \pm 14 \mathrm{bpm}$ after; $n=6$; paired $t$-test, $p=0.005)$. The pre-treatment with catalase abolished the pressor response (vehicle: $38 \pm 5 \mathrm{mmHg}$ versus catalase: $9 \pm 2 \mathrm{mmHg} ; p<0.001 ; n=6$; ANOVA one way followed by Student-Newman-Keuls) and bradycardic response (vehicle: $-51 \pm 12 \mathrm{bpm}$ versus catalase: $-6 \pm 4 \mathrm{bpm} ; p=0.004$; $n=6$; ANOVA one way followed by Student-Newman-Keuls) induced by $\mathrm{H}_{2} \mathrm{O}_{2}(1.0 \mu \mathrm{mol} / 0.5 \mu \mathrm{L} / \mathrm{rat})$ into the 4 th $\mathrm{V}$ (Fig. 4).

\subsection{Effect of i.v. atropine on central $\mathrm{H}_{2} \mathrm{O}_{2}$-induced pressor and bradycardic responses}

Intravenous injection of the muscarinic receptor blocker atropine methyl bromide $(1.0 \mathrm{mg} / \mathrm{kg}$ of body weight $)$ increased HR (331 $\pm 9 \mathrm{bpm}$ before versus $428 \pm 9 \mathrm{bpm}$ after atropine, $n=11$; paired $t$-test, $p<0.001)$ and MAP $(117 \pm 13 \mathrm{mmHg}$ before versus $125 \pm 3 \mathrm{mmHg}$ after atropine, $n=11$; paired $t$-test, $p=0.024)$. Pre-treatment with atropine completely blocked the bradycardic response to injection of $1 \mu \mathrm{mol}$ of $\mathrm{H}_{2} \mathrm{O}_{2}$ into the 4th V, but did not affect the pressor response (Fig. 5).

\subsection{Effect of i.v. prazosin on central $\mathrm{H}_{2} \mathrm{O}_{2}$-induced pressor and bradycardic responses}

Intravenous administration of the $\alpha_{1}$ adrenergic receptor blocker prazosin $(1.0 \mathrm{mg} / \mathrm{kg}$ of body weight) increased HR (from $312 \pm 15$ to $430 \pm 22 \mathrm{bpm}, n=6$; paired $t$-test, $p=0.002$ ) without changing baseline MAP (from $108 \pm 1$ to $102 \pm 2 \mathrm{mmHg}$; paired $t$-test, $p=0.142$ ). Instead of the pressor responses produced by $\mathrm{H}_{2} \mathrm{O}_{2}$ into the 4 th $\mathrm{V}$ in control tests, after i.v. prazosin, $\mathrm{H}_{2} \mathrm{O}_{2}$ into the 4th $\mathrm{V}$ reduced MAP (Fig. 6). The bradycardia to $\mathrm{H}_{2} \mathrm{O}_{2}$ in the 4th $\mathrm{V}$ was not affected by i.v. prazosin (Fig. 6).

\section{Discussion}

The present results show that $\mathrm{H}_{2} \mathrm{O}_{2}$ injected into the 4th $\mathrm{V}$ simultaneous and through independent mechanisms activates sympathetic and parasympathetic systems inducing pressor and bradycardic responses. The pressor responses are transitory (less than $1 \mathrm{~h}$ ), while bradycardia with the high dose ( $1.5 \mu \mathrm{mol} / \mathrm{rat})$ lasted for $24 \mathrm{~h}$. These responses were abolished (pressor response) or reduced (bradycardia) by pre-treatment with the anti-oxidant NAC suggesting that they depend on central increases in ROS.

The peripheral blockade of muscarinic receptors with atropine abolished $\mathrm{H}_{2} \mathrm{O}_{2}$-induced bradycardia, without changing the pressor response, which suggests that $\mathrm{H}_{2} \mathrm{O}_{2}$-induced bradycardia is totally dependent on increases in vagal discharges. On the other hand, peripheral blockade of $\alpha_{1}$ adrenoceptors with prazosin abolished the pressor response elicited by $\mathrm{H}_{2} \mathrm{O}_{2}$, suggesting that increased ROS in the brainstem stimulate sympathetic discharges causing vasoconstriction and increase in arterial pressure. In spite of the blockade of the pressor response, the bradycardia produced by $\mathrm{H}_{2} \mathrm{O}_{2}$ was not modified by i.v. prazosin, which suggests that the bradycardia is not the result of baroreflex activation. Moreover, after prazosin, $\mathrm{H}_{2} \mathrm{O}_{2}$ into the 4th $\mathrm{V}$ induced a small hypotension, probably a consequence of the bradycardia still present.

Differently from the transitory (less than $1 \mathrm{~h}$ ) pressor responses, the bradycardia with the high dose of $\mathrm{H}_{2} \mathrm{O}_{2}$ into the 4 th was still present $24 \mathrm{~h}$ later, which suggests that parasympathetic tone remains modified for at least $24 \mathrm{~h}$. The bradycardia is completely reversed and HR return to control levels $48 \mathrm{~h}$ after $\mathrm{H}_{2} \mathrm{O}_{2}$ injections, which suggests that bradycardia could result from an irreversible oxidation of pivotal structures involved in the neurotransmission that are replaced by turnover from 24 to $48 \mathrm{~h}$ after $\mathrm{H}_{2} \mathrm{O}_{2}$ injections. The different time-course of pressor and bradycardic responses and the effects of $i . v$. prazosin and atropine suggest that independent mechanisms are activated by $\mathrm{H}_{2} \mathrm{O}_{2}$ into the 4 th $\mathrm{V}$ to produce these two responses.

The activity of sympathetic and parasympathetic systems is under the control of a medullary circuitry comprising the NTS, 

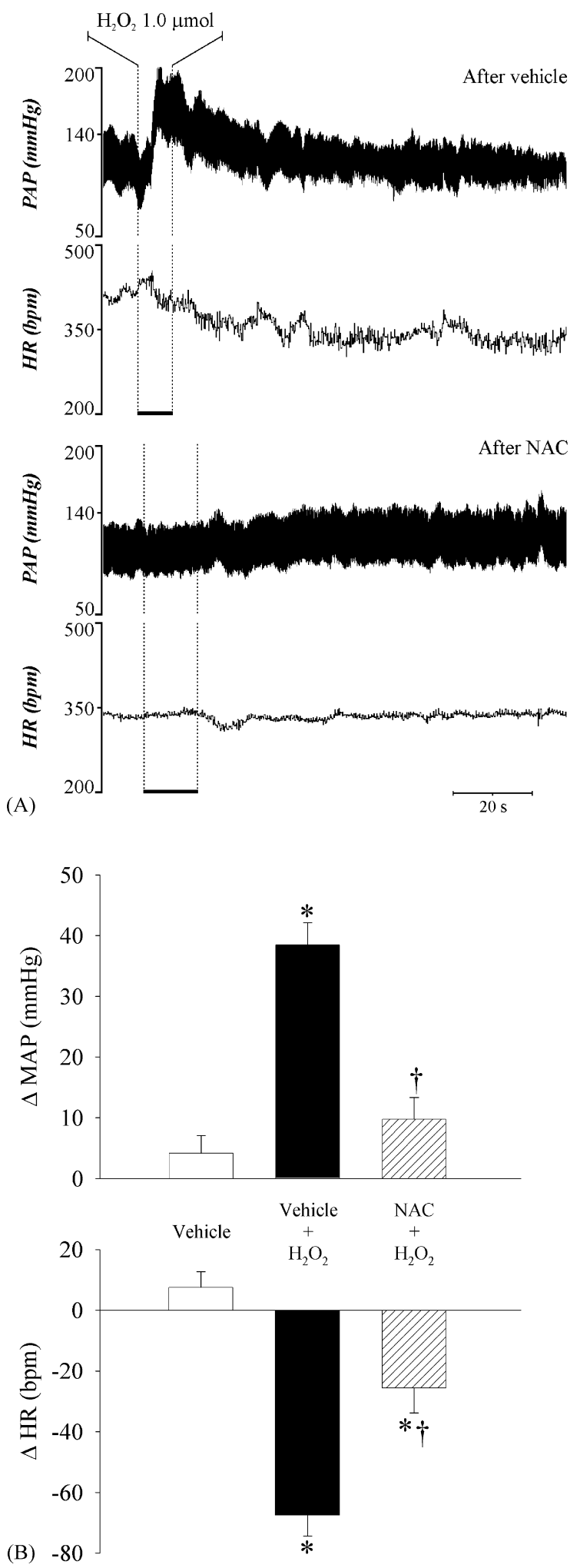

Fig. 3. (A) Recordings of pulsatile arterial pressure (PAP) and HR in a rat of the group that received NAC $(250 \mathrm{nmol} / 1 \mu \mathrm{L} / \mathrm{rat})$ into the 4 th $\mathrm{V}$ prior to $\mathrm{H}_{2} \mathrm{O}_{2}$ $(1.0 \mu \mathrm{mol} / 0.5 \mu \mathrm{L} / \mathrm{rat}$ ) in the same place; (B) changes in MAP ( $\triangle \mathrm{MAP})$ and $\mathrm{HR}$ $(\Delta \mathrm{HR})$ produced by $\mathrm{H}_{2} \mathrm{O}_{2}(1.0 \mu \mathrm{mol} / 0.5 \mu \mathrm{L} / \mathrm{rat})$ injected into the 4 th $\mathrm{V}$ after vehicle or NAC injection in the same place. NAC: $n=6$; vehicle: $n=6 . *$ Different from the vehicle; $\uparrow$ different from $\mathrm{H}_{2} \mathrm{O}_{2}$ after vehicle $(p<0.05$, ANOVA one way followed by Student-Newman-Keuls test).
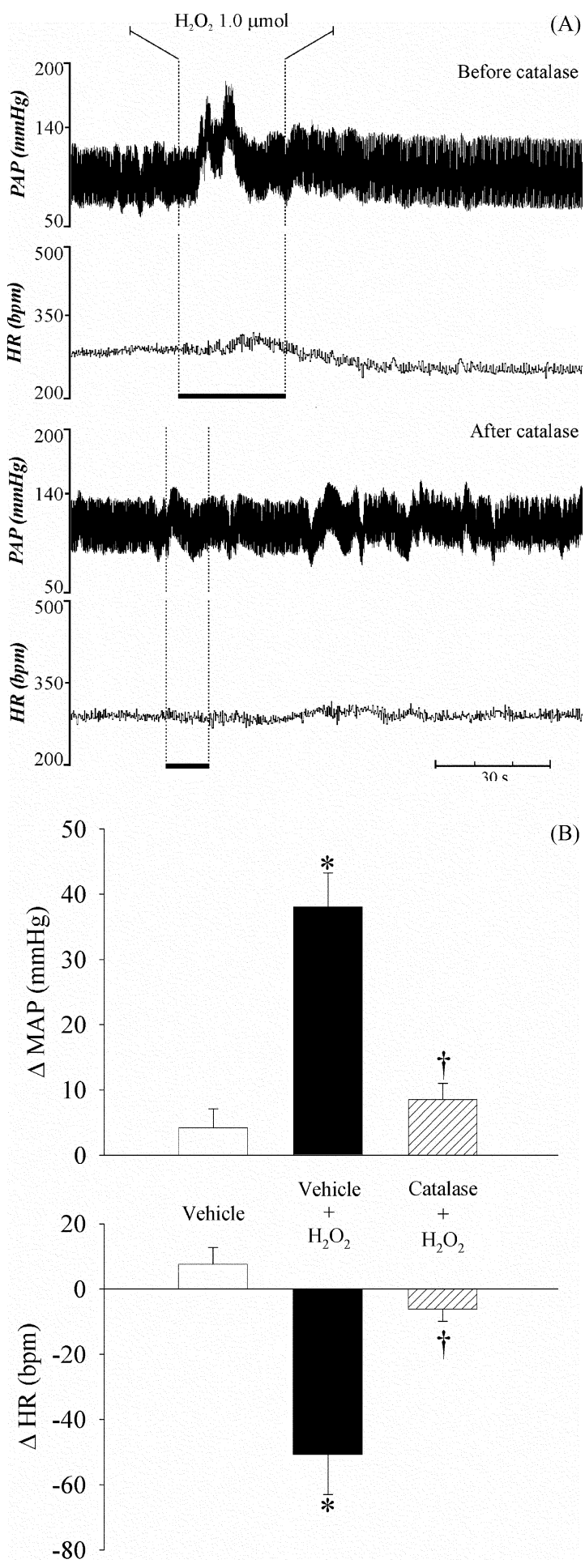

Fig. 4. (A) Recordings of pulsatile arterial pressure (PAP) and HR in a rat of the group that received catalase $(500 \mathrm{UAE} / 1 \mu \mathrm{L} / \mathrm{rat})$ into the 4 th $\mathrm{V}$ prior to $\mathrm{H}_{2} \mathrm{O}_{2}(1.0 \mu \mathrm{mol} / 0.5 \mu \mathrm{L} / \mathrm{rat})$ in the same place; (B) changes in MAP ( $\triangle \mathrm{MAP}$ ) and $\mathrm{HR}(\Delta \mathrm{HR})$ produced by $\mathrm{H}_{2} \mathrm{O}_{2}(1.0 \mu \mathrm{mol} / 0.5 \mu \mathrm{L} /$ rat $)$ injected into the 4 th $\mathrm{V}$ before and after injection of catalase or vehicle in the same place. Catalase: $n=6$; vehicle: $n=6$. $^{*}$, Different from the vehicle; $\dagger$ different from $\mathrm{H}_{2} \mathrm{O}_{2}$ after vehicle $(p<0.05$, ANOVA one way for repeated measures followed by Student-Newman-Keuls test). 

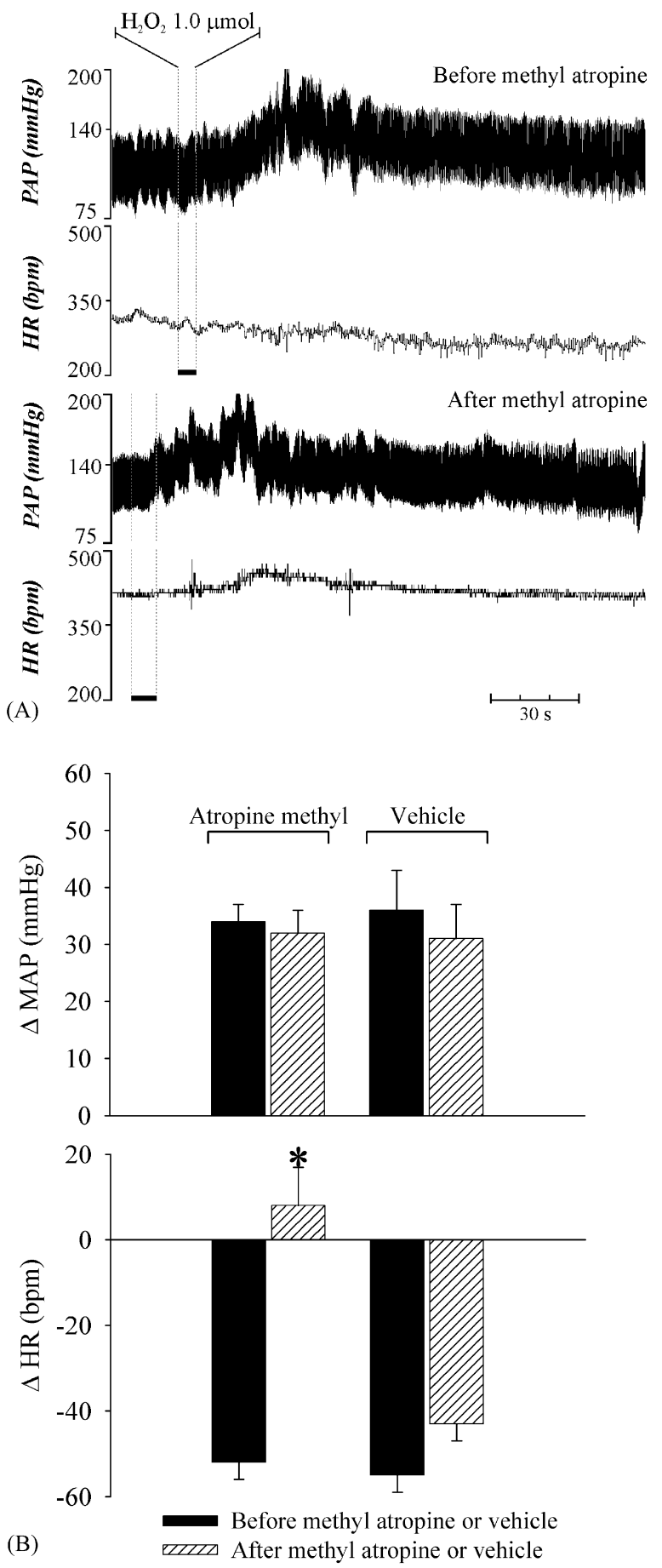

Fig. 5. (A) Recordings of pulsatile arterial pressure (PAP) and $\mathrm{HR}$ in a rat of the group that received atropine i.v. prior to $\mathrm{H}_{2} \mathrm{O}_{2}(1.0 \mu \mathrm{mol} / 0.5 \mu \mathrm{L} / \mathrm{rat})$ into the 4 th $\mathrm{V}$; (B) changes in MAP $(\triangle \mathrm{MAP})$ and $\mathrm{HR}(\Delta \mathrm{HR})$ produced by $\mathrm{H}_{2} \mathrm{O}_{2}(1.0 \mu \mathrm{mol} / 0.2 \mu \mathrm{L} / \mathrm{rat})$ injected into the 4 th $\mathrm{V}$ before and after injections of atropine methyl $(1 \mathrm{mg} / \mathrm{kg}$ b.w. $)$ or vehicle i.v. Atropine: $n=11$; vehicle: $n=6$. "*, Different from the responses before atropine methyl and after pretreatment with vehicle $(p<0.05$, paired $t$-test and ANOVA one way followed by Student-Newman-Keuls test, respectively).

RVLM, caudal ventrolateral medulla (CVLM) and the nucleus ambiguous. The RVLM controls the sympathetic discharges activating pre-ganglionic sympathetic neurons in the spinal cord, while the nucleus ambiguous controls parasympathetic activity
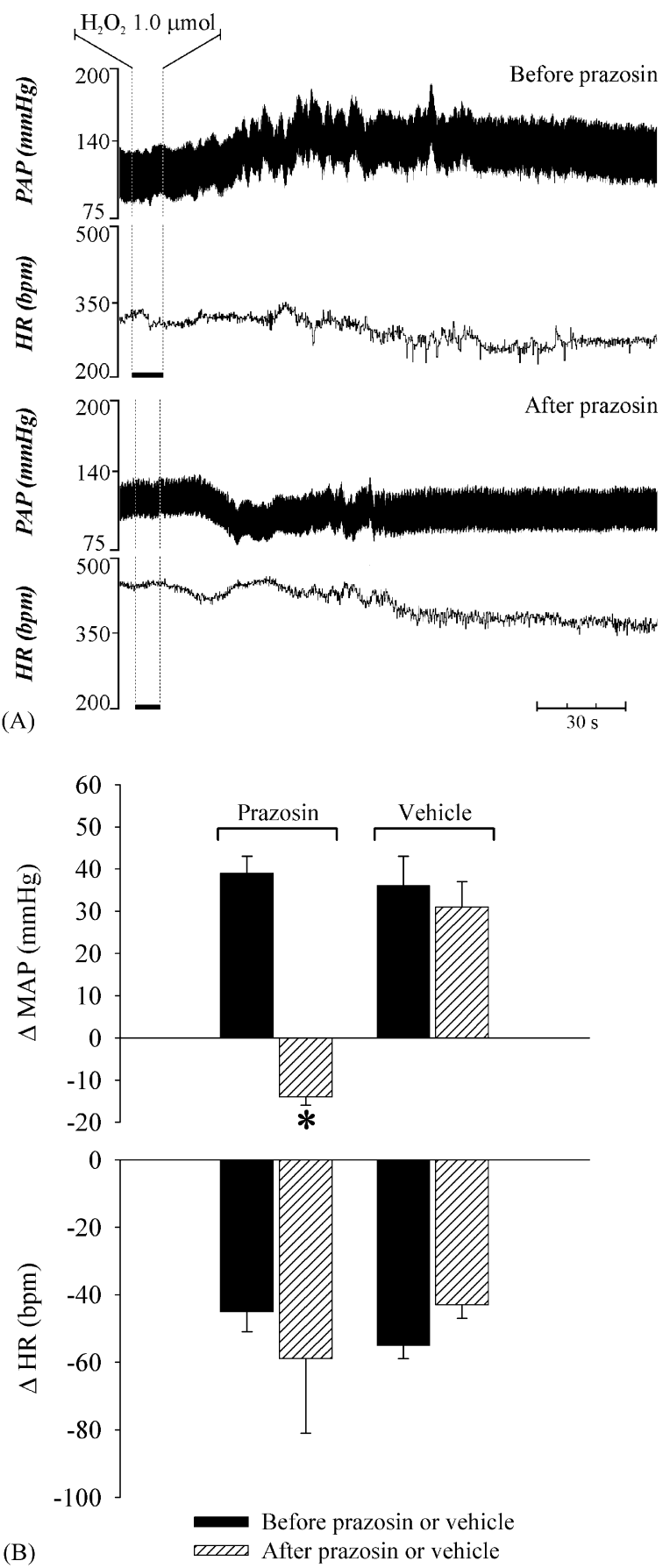

Fig. 6. (A) Recordings of pulsatile arterial pressure (PAP) and HR in a rat of the group that received prazosin i.v. prior to $\mathrm{H}_{2} \mathrm{O}_{2}(1.0 \mu \mathrm{mol} / 0.5 \mu \mathrm{L} / \mathrm{rat})$ into the 4th $\mathrm{V}$; (B) changes in MAP $(\triangle \mathrm{MAP})$ and $\mathrm{HR}(\triangle \mathrm{HR})$ produced by $\mathrm{H}_{2} \mathrm{O}_{2}(1.0 \mu \mathrm{mol} / 0.2 \mu \mathrm{L} / \mathrm{rat})$ injected into the 4 th $\mathrm{V}$ before and after injections of prazosin $\left(1 \mathrm{mg} / \mathrm{kg}\right.$ b.w.) or vehicle i.v. Prazosin: $n=6$; vehicle: $n=6$. ${ }^{*}$ ' Different from the responses before prazosin and after pre-treatment with vehicle $(p<0.05$, paired $t$-test and ANOVA one way followed by Student-Newman-Keuls test, respectively).

[36]. The RVLM and nucleus ambiguous are influenced by signals arising from the NTS, the site of the first synapse of baro and chemoreceptor afferents $[26,27,37]$. The $\mathrm{H}_{2} \mathrm{O}_{2}$ injected into the 4th $\mathrm{V}$ may easily reach structures surrounding the ventricular system like the area postrema, NTS and the dorsal motor 
nucleus of the vagus (see Fig. 1). The stimulation of these areas by $\mathrm{H}_{2} \mathrm{O}_{2}$ or any other ROS that result from $\mathrm{H}_{2} \mathrm{O}_{2}$ into the 4th $\mathrm{V}$ may activate the nucleus ambiguous and the RVLM causing increases in sympathetic activity and cardiac parasympathetic tone, producing pressor and bradycardic responses.

By increasing the rate of endogenous or exogenous $\mathrm{H}_{2} \mathrm{O}_{2}$ conversion to $\mathrm{H}_{2} \mathrm{O}$ and $\mathrm{O}_{2}$, the injection of catalase into the 4 th $\mathrm{V}$ almost abolished the pressor and bradycardic responses to $\mathrm{H}_{2} \mathrm{O}_{2}$ into the 4th $\mathrm{V}$. This result suggests that any increase in local $\mathrm{O}_{2}$ availability produced $\mathrm{H}_{2} \mathrm{O}_{2}$ injection into the 4 th $\mathrm{V}$ is not the cause of the cardiovascular responses to the $\mathrm{H}_{2} \mathrm{O}_{2}$. In addition, injection of the low molecular weight anti-oxidant NAC, a scavenger of ROS that reacts promptly with $\mathrm{HO}^{\bullet}$ but slowly with $\mathrm{H}_{2} \mathrm{O}_{2}$ [2], abolished the pressor response and reduced bradycardia induced by $\mathrm{H}_{2} \mathrm{O}_{2}$. Taken together, these results suggest that $\mathrm{H}_{2} \mathrm{O}_{2}$ and/or its electrophilic metabolites into the 4th $\mathrm{V}$ or in surrounding tissues activate hindbrain pathways that increase sympathetic and parasympathetic activity inducing pressor and bradycardic responses.

Eventual neuronal lesions by $\mathrm{H}_{2} \mathrm{O}_{2}$ injections are probably not the cause of the effects described in the present study. A previous study demonstrated that superfusion of spinal chord slices for $3 \mathrm{~min}$ with $0.3 \mathrm{mmol} / \mathrm{L}$ of $\mathrm{H}_{2} \mathrm{O}_{2}$ (a dose 300 -fold higher than the median dose used in the present study) had no effect on excitatory or inhibitory post-synaptic potentials in whole cell recording of neurons [25]. Additionally, superfusion with $1 \mathrm{mmol} / \mathrm{L}$ of $\mathrm{H}_{2} \mathrm{O}_{2}$ produced an increase in the peak amplitude of the excitatory post-synaptic potentials that was reversed after washing the tissue. Such finds suggest no irreversible damage of neurons exposed to $\mathrm{H}_{2} \mathrm{O}_{2}$ concentration around 1000fold higher than the mean dose used in the present study. The dose-response effects of $\mathrm{H}_{2} \mathrm{O}_{2}$ injected into the 4 th $\mathrm{V}$, the recovery of MAP and HR to pre-injection levels and the blockade or the reduction of the responses after the treatment with NAC and catalase also suggest that the effects of $\mathrm{H}_{2} \mathrm{O}_{2}$ observed in the present study are due to a physiological or pharmacological action in brain, rather than to non-specific damage of neural tissue.

The neural or cellular mechanisms activated by $\mathrm{H}_{2} \mathrm{O}_{2}$ to produce cardiovascular responses are still not clear. The present results strongly suggest that oxidative modifications in the hindbrain activate neural mechanisms involved with sympathetic and parasympathetic control. Previous studies have shown that $\mathrm{H}_{2} \mathrm{O}_{2}$ might change cell membrane conductance to potassium [35] or calcium [28]. Evidence also suggests that $\mathrm{H}_{2} \mathrm{O}_{2}$ and other ROS can increase the availability of excitatory amino acids into the synaptic cleft $[6,30,38]$. Similar to the present results with $\mathrm{H}_{2} \mathrm{O}_{2}$ injected into the 4 th $\mathrm{V}$, injections of glutamate into the NTS of unanesthetized rats induce pressor and bradycardic responses due to simultaneous activation of sympathetic and parasympathetic systems [10]. Therefore similar mechanisms may be shared by $\mathrm{H}_{2} \mathrm{O}_{2}$ and glutamate to produce cardiovascular responses and perhaps the increase of glutamate release may play a role on cardiovascular responses to $\mathrm{H}_{2} \mathrm{O}_{2}$ into the 4 th V. Changes in ion conductance by neuron membrane and/or in neurotransmission at hindbrain level are possibilities that need further investigation.
Previous studies have also proposed the participation of ROS in the control of arterial pressure in physiological and pathological conditions. Increases in the generation of free radicals, especially superoxide, into the central nervous system is suggested to increase sympathetic activity $[18,40,43,45]$. A close relationship between hypertension and increases in ROS generation in different tissues like endothelium, vessel smooth muscles or even in some parts of the central nervous system like the subfornical organ has been reported [5,7,12,14,15,20,44,24,39,41,46]. Injections of the SOD mimetic 4-hydroxyl 2,2,6,6-tetramethyl peperidine-1-oxyl (tempol) into the RVLM caused a dosedependent fall in the arterial pressure in spontaneously hypertensive rats (SHR) without changing arterial pressure in normotensive rats [22]. Injection of the SOD enzyme into the RVLM of pigs reduced renal sympathetic nerve activity and arterial pressure [43]. Moreover, i.v. injection of tempol reduced arterial pressure and heart rate [42] whereas continuous (1 week) intracisternal infusion of tempol did not affect these parameters in normotensive rats [21]. Although these studies suggest that imbalances in ROS production may play a role in hypertension, the mechanisms involved are still not clear because the studies did not show if the decrease in arterial pressure produced by tempol or SOD is dependent on reduction of $\mathrm{O}_{2}{ }^{\bullet-}$, increases in $\mathrm{H}_{2} \mathrm{O}_{2}$ formation or both. According to the present results, an oxidative burst produced by injections of $\mathrm{H}_{2} \mathrm{O}_{2}$ into the 4th $\mathrm{V}$ activate hindbrain mechanisms related to cardiovascular control increasing simultaneously and through independent mechanisms sympathetic and parasympathetic discharges to produce pressor and bradycardic responses.

\section{Acknowledgments}

The authors thank Dr. Gus Schoorlemmer for his comments and suggestions that helped to improve the manuscript, Reginaldo C. Queiroz, Silas P. Barbosa and Silvia Fóglia for expert technical assistance and Silvana A. D. Malavolta for secretarial assistance. We also thank Ana L.V. de Oliveira for animal care. This research was supported by public funding from Fundação de Amparo à Pesquisa do Estado de São Paulo (FAPESP), Conselho Nacional de Pesquisa (CNPq)/PRONEX and Coordenação de Aperfeiçoamento de Pessoal de Nível Superior (Capes).

\section{References}

[1] V. Adler, Z. Yin, K.D. Tew, Z. Ronai, Role of redox potential and reactive oxygen species in stress signaling, Oncogene 18 (1999) 6104-6111.

[2] O.I. Aruoma, B. Halliwell, B.M. Hoey, J. Butler, The antioxidant action of $\mathrm{N}$-acetylcysteine: its reaction with hydrogen peroxide, hydroxyl radical, superoxide, and hypochlorous acid, Free Rad. Biol. Med. 6(1989) 593-597.

[3] J.M. Auerbach, M. Segal, Peroxide modulation of slow onset potentiation in rat hippocampus, J. Neurosci. 17 (1997) 8695-8701.

[4] M.V. Avshalumov, M.E. Rice, NMDA receptor activation mediates hydrogen peroxide-induced pathophysiology in rat hippocampal slices, J. Neurophysiol. 87 (2002) 2896-2903.

[5] M.A. Bayorh, A.A. Ganafa, R.R. Socci, N. Silvestrov, I.K. Abukhalaf, The role of oxidative stress in salt-induced hypertension, Am. J. Hypertens. 17 (2004) 31-36.

[6] S.C. Bondy, D.K. Lee, Oxidative stress induced by glutamate receptor agonists, Brain Res. 610 (1993) 229-233. 
[7] H. Cai, D.G. Harrison, Endothelial dysfunction in cardiovascular diseases: the role of oxidant stress, Circ. Res. 87 (2000) 840-844.

[8] A. Ceriello, D. Giugliano, A. Quatraro, P.J. Lefebvre, Anti-oxidants show an anti-hypertensive effect in diabetic and hypertensive subjects, Clin. Sci. (Lond.) 81 (1991) 739-742.

[9] B.T. Chen, M.V. Avshalumov, M.E. Rice, H(2)O(2) is a novel, endogenous modulator of synaptic dopamine release, J. Neurophysiol. 85 (2001) 2468-2476.

[10] E. Colombari, J.V. Menani, W.T. Talman, Commissural NTS contributes to pressor responses to glutamate injected into the medial NTS of awake rats, Am. J. Physiol. 270 (1996) R1220-R1225.

[11] E. Colombari, M.A. Sato, S.L. Cravo, C.T. Bergamaschi, R.R. Campos Jr., O.U. Lopes, Role of the medulla oblongata in hypertension, Hypertension 38 (2001) 549-554.

[12] C. Csonka, T. Pataki, P. Kovacs, S.L. Muller, M.L. Schroeter, A. Tosaki, I.E. Blasig, Effects of oxidative stress on the expression of antioxidative defense enzymes in spontaneously hypertensive rat hearts, Free Rad. Biol. Med. 29 (2000) 612-619.

[13] R.A. Dampney, Functional organization of central pathways regulating the cardiovascular system, Physiol. Rev. 74 (1994) 323-364.

[14] N.S. Dhalla, R.M. Temsah, T. Netticadan, Role of oxidative stress in cardiovascular diseases, J. Hypertens. 18 (2000) 655-673.

[15] A.D. Dobrian, S.D. Schriver, R.L. Prewitt, Role of angiotensin II and free radicals in blood pressure regulation in a rat model of renal hypertension, Hypertension 38 (2001) 361-366.

[16] M.V. Frantseva, J.L. Perez Velazquez, P.L. Carlen, Changes in membrane and synaptic properties of thalamocortical circuitry caused by hydrogen peroxide, J. Neurophysiol. 80 (1998) 1317-1326.

[17] H.F. Galley, J. Thornton, P.D. Howdle, B.E. Walker, N.R. Webster, Combination oral antioxidant supplementation reduces blood pressure, Clin. Sci. (Lond.) 92 (1997) 361-365.

[18] L. Gao, W. Wang, Y.L. Li, H.D. Schultz, D. Liu, K.G. Cornish, I.H. Zucker, Superoxide mediates sympathoexcitation in heart failure: roles of angiotensin II and NAD(P)H oxidase, Circ. Res. 95 (2004) 937-944.

[19] B. Halliwell, Reactive oxygen species and the central nervous system, J. Neurochem. 59 (1992) 1609-1623.

[20] H.J. Hong, G. Hsiao, T.H. Cheng, M.H. Yen, Supplemention with tetrahydrobiopterin suppresses the development of hypertension in spontaneously hypertensive rats, Hypertension 38 (2001) 1044-1048.

[21] Y. Kimura, Y. Hirooka, Y. Sagara, K. Ito, T. Kishi, H. Shimokawa, A. Takeshita, K. Sunagawa, Overexpression of inducible nitric oxide synthase in rostral ventrolateral medulla causes hypertension and sympathoexcitation via an increase in oxidative stress, Circ. Res. 96 (2005) 252 260.

[22] T. Kishi, Y. Hirooka, Y. Kimura, K. Ito, H. Shimokawa, A. Takeshita, Increased reactive oxygen species in rostral ventrolateral medulla contribute to neural mechanisms of hypertension in stroke-prone spontaneously hypertensive rats, Circulation 109 (2004) 2357-2362.

[23] F. Lacy, D.T. O’Connor, G.W. Schmid-Schonbein, Plasma hydrogen peroxide production in hypertensives and normotensive subjects at genetic risk of hypertension, J. Hypertens. 16 (1998) 291-303.

[24] L.O. Lerman, K.A. Nath, M. Rodriguez-Porcel, J.D. Krier, R.S. Schwartz, C. Napoli, J.C. Romero, Increased oxidative stress in experimental renovascular hypertension, Hypertension 37 (2001) 541-546.

[25] H.H. Lin, C.H. Chen, W.K. Hsieh, T.H. Chiu, C.C. Lai, Hydrogen peroxide increases the activity of rat sympathetic preganglionic neurons in vivo and in vitro, Neuroscience 121 (2003) 641-647.
[26] A.D. Loewy, Central autonomic pathways, in: A.D. Loewy, K.M. Spyer (Eds.), Central Regulation of Autonimic Functions, Oxford University Press, 1990, pp. 88-103.

[27] B.H. Machado, H. Mauad, D.A. Chianca Junior, A.S. Haibara, E. Colombari, Autonomic processing of the cardiovascular reflexes in the nucleus tractus solitarii, Braz. J. Med. Biol. Res. 30 (1997) 533-543.

[28] H.F. Moghadam, W. Winlow, L.L. Moroz, Effects of hydrogen peroxide and nitric oxide (NO) on neuronal discharges and intracellular calcium concentration in the molluscan CNS, Acta Biol. Hung. 46 (1995) 145-153.

[29] G. Paxinos, C. Watson, The Rat Brain in Stereotaxic Coordinates, Academic Press, 1997.

[30] D.E. Pellegrini-Giampietro, G. Cherici, M. Alesiani, V. Carla, F. Moroni, Excitatory amino acid release from rat hippocampal slices as a consequence of free-radical formation, J. Neurochem. 51 (1988) 1960-1963.

[31] T. Pellmar, Electrophysiological correlates of peroxide damage in guinea pig hippocampus in vitro, Brain Res. 364 (1986) 377-381.

[32] L. Pogan, L. Garneau, P. Bissonnette, L. Wu, R. Sauve, Abnormal Ca2+ signalling in vascular endothelial cells from spontaneously hypertensive rats: role of free radicals, J. Hypertens. 19 (2001) 721-730.

[33] D.J. Reis, The brain and hypertension: reflections on 35 years of inquiry into the neurobiology of the circulation, Circulation 70 (1984) III31-III45.

[34] S.G. Rhee, T.S. Chang, Y.S. Bae, S.R. Lee, S.W. Kang, Cellular regulation by hydrogen peroxide, J. Am. Soc. Nephrol. 14 (2003) S211-S215.

[35] V. Seutin, J. Scuvee-Moreau, L. Massotte, A. Dresse, Hydrogen peroxide hyperpolarizes rat CA1 pyramidal neurons by inducing an increase in potassium conductance, Brain Res. 683 (1995) 275-278.

[36] S.L. Stuesse, Origins of cardiac vagal preganglionic fibers: a retrograde transport study, Brain Res. 236 (1982) 15-25.

[37] A.F. Sved, F.J. Gordon, Amino acids as central neurotransmitters in the barorecepor reflex pathway, News Physiol. Sci. 9 (1994) 243-246.

[38] D. Trotti, N.C. Danbolt, A. Volterra, Glutamate transporters are oxidantvulnerable: a molecular link between oxidative and excitotoxic neurodegeneration? Trends Pharmacol. Sci. 19 (1998) 328-334.

[39] S. Vasdev, C.A. Ford, S. Parai, L. Longerich, V. Gadag, Dietary vitamin C supplementation lowers blood pressure in spontaneously hypertensive rats, Mol. Cell Biochem. 218 (2001) 97-103.

[40] G. Wang, J. Anrather, J. Huang, R.C. Speth, V.M. Pickel, C. Iadecola NADPH oxidase contributes to angiotensin II signaling in the nucleus tractus solitarius, J. Neurosci. 24 (2004) 5516-5524.

[41] R. Wu, E. Millette, L. Wu, J. de Champlain, Role of oxidative stress in the development of hypertension in SHR, Am. J. Hypertens. 14 (2001) A134, Ref Type: Abstract.

[42] H. Xu, G.D. Fink, J.J. Galligan, Tempol lowers blood pressure and sympathetic nerve activity but not vascular $\mathrm{O}^{2-}$ in DOCA-salt rats, Hypertension 43 (2004) 329-334.

[43] J. Zanzinger, J. Czachurski, Chronic oxidative stress in the RVLM modulates sympathetic control of circulation in pigs, Pflugers Arch. 439 (2000) 489-494.

[44] J. Zich, Antihypertensive effect of chronic antioxidant treatment by $n$ acetylcysteine in rats with 1-NAME hypertension. Abstract Book Hypertension 200422 (2004) 13S. São Paulo. Ref Type: Abstract.

[45] M.C. Zimmerman, E. Lazartigues, J.A. Lang, P. Sinnayah, I.M. Ahmad, D.R. Spitz, R.L. Davisson, Superoxide mediates the actions of angiotensin II in the central nervous system, Circ. Res. 91 (2002) 1038-1045.

[46] M.C. Zimmerman, E. Lazartigues, R.V. Sharma, R.L. Davisson, Hypertension caused by angiotensin II infusion involves increased superoxide production in the central nervous system, Circ. Res. 95 (2004) 210-216. 